\title{
THE IMPLEMENTATION OF LINK 16 IN THE POLISH ARMED FORCES AND ITS INFLUENCE ON DEFENCE CAPABILITIES, NATIONAL SECURITY AND IMAGE OF POLAND AS A NATO MEMBER
}

\author{
Andrzej Orzol \\ Polish Air Force Communications and Information Systems Center
}

\begin{abstract}
The article shows the history and origins of Tactical Data Systems, their structure and purposes in countries who are members of North Atlantic Treaty Organization with the emphasis on LINK 16 standard. It describes the effect of LINK 16 implementation in the Polish Armed Forces on Poland's interoperability as a fully - fledged NATO member thus increasing defense capabilities, national security and enhancing the Polish Armed Forces' image in the international arena. What is more, typical examples of Tactical Data Links operations during military exercises, in peacetime and while trying to solve geopolitical, military conflicts in the world have also been characterized.
\end{abstract}

Keywords: Link 16, Tactical Data Systems, Data Security, Polish Armed Forces, NATO.

\section{Tactical Data Systems origins}

When analyzing and evaluating the effectiveness of military operations (no matter whether we consider recent events or those from the past) while trying to solve various conflicts, we draw the obvious conclusion that information, its correctness, credibility and time of delivery have always played crucial (especially in the contemporary battlefield reality) role in gaining tactical advantage, achieving appointed goals and ensuring victory.

Taking ancient or medieval wars and battles, commanders would exchange tactical and other information sending messengers in which significant delay was inherent. Another equally important disadvantage of the above mentioned data transfer process was almost complete lack of information security, that is probable loss of:

a) confidentiality - when an enemy intercepts information/data;

b) integrity - when information/data was modified in order to misinform and/ or mislead the receiver;

c) availability of a message being transported - when a messenger cannot reach the intended destination.

Moreover, a sender would receive (or not) the confirmation of the fact that the message was successfully received with great delay as well. All of the above would have great negative influence on the processes of tactical and strategic decision making performed by commanders.

Taking into consideration historical events and military experience people have always made strenuous efforts in order to eliminate or at least minimize the above 
mentioned disadvantages by using faster means of transport, providing proper security and implementing protection measures to preclude an enemy from deciphering information. With the passing centuries, consecutive leaps forwards in civilization and the advent of innovative technologies, both speed and security of any transferred data increased significantly. However, no one could have achieve $100 \%$ certainty that the message with no unwanted modifications would reach its destination in real time - with almost no delay. Such concepts of functionality, efficiency and effectiveness of military data transfer have inspired the very first architects of tactical data systems. The typical example of standards used in tactical data systems is LINK 16 that enables to securely exchange data in near real time - with almost no delay.

LINK 16 is one of the standards utilized by armed forces of NATO members, among them: Link 1, LINK 4, LINK 11A, LINK 11B, LINK 16, LINK 22 and others. Current state of affairs in this respect in Poland is that we have implemented LINK 11 in the Navy and LINK 16 in the Air Force.

\section{Basic information on tactical data links within NATO:}

LINK 1 - developed in the fifties, not secured (no cryptographic measures implemented), duplex connection, designed to exchange recognized air picture data point-to-point among air control and air operation centers ${ }^{1}$.

LINK 4 - semi-duplex connection with no crypto measures implemented, no jamming resistance, designed to exchange data between aircraft and air control.

LINK $11 \mathrm{~A}$ - developed in the sixties relatively slow connection, semi-duplex. It enables to exchange tracks and data from early warning systems among control and command centers. Secure connection - crypto measures implemented but with no jamming resistance. It is not capable of commanding and controlling aircraft ${ }^{2}$.

LINK 11B - duplex connection point-to-point with more capabilities than $11 \mathrm{~A}$. It enables to command and control aircraft ${ }^{3}$.

LINK 22 - secured cryptographically and jamming resistant tactical data link developed in 1992 with the aim of replacing LINK 11 and ensuring interoperability with LINK 16 under the NILE - NATO Improved LINK 11 program. In comparison with all other data links LINK 22 has better characteristics when it comes to network planning and management ${ }^{4}$.

LINK 16 - developed in 1994 in the US Navy and US Air Force is one of the most modern standards capable of exchanging various data formats such as text, pictures and voice among command and control locations, combat units, radar systems and

1 NATO Standardization Office NATO STANAG 5501 Tactical Data Exchange - Link 1, Brussels.

2 NATO Standardization Office NATO STANAG 5511 Tactical Data Exchange - Link 11, Brussels.

3 Ibidem.

4 NATO Standardization Office STANAG 5522 Tactical Data Exchange - Link 22, Brussels. 
all other war theatre participants provided that they are equipped with MIDS LVT (Multifunctional Information Distribution System Low Volume Terminal). The term LINK 16 was also a name of the Polish, military tactical data system based on LINK 16 standard designed to exchange tactical information classified NATO SECRET during national and allied operations. Current name of the system is Rosiczka. LINK 16 standard was produced as a consecutive, considerably improved version of LINK 11, that in comparison has been enhanced in terms of: data transfer security (better anti-jamming capability), throughput (speed), size of data transmitted, range and decreased probability of data loss. The standard enables to exchange cryptographically secured tactical data in close to real time among all the branches (Air Force, Army, Navy and Special Forces). Communications security is provided thanks to sophisticated anti-jamming capability and encryption of both transmission and messages themselves (TSEC - transmission security and MSEC - message security). Information exchange via radio waves between system terminals is a way to exchange information on blue (allied) and red (enemy - from military intelligence) troops location as well as control and command of the forces 5 .

Taking all the above into consideration, tactical data links such as LINK 16 have a significant influence on interoperability since it is widely used by NATO members and other allied forces.

The planning and implementation of LINK 16 tactical data system processes in Poland have started at the very beginning of this century. A special body - organizational unit has been established within the structure of General Staff of the Polish Armed Forces, tasked with completely new issues then, such as tactical data systems and global positioning systems called Tactical Data Systems and Navstar GPS Group. It was created in order to take care of all the aspects related to LINK 16 implementation to the Polish Armed Forces. The Group was a precursor of a completely unknown issue then, uncharted territory and played a crucial role in the above mentioned process. After a Road Map to implement LINK 16 in the Polish Armed Forces had been proposed by the Group, it was given a seal of approval by the Chief of the Polish General Staff. A profusion of units and institutions such as the Armament Inspectorate, the Inspectorate for the Polish Armed Forces Support and the Polish Air Force Communications and Information Systems Center were tasked with particular activities in this respect thus starting to implement the planned objectives. The very first branch capable of using LINK 16 standard was the Polish Air Force simply due to the fact that Poland had already bought multirole F-16 jet fighters equipped with MIDS LVT terminals utilized in two Air Force Bases. Along with the aircraft, GSS AGILE (Ground Support System Aerosystems Generic Integrated Link Environment) site in Poznań-Krzesiny Base was

5 NATO Standardization Office NATO STANAG 5516 Tactical Data Exchange - Link 16, Brussels. 
set up. Its main purpose is to facilitate training of both platform/terminal operators (pilots) as well as ground crews, particularly avionics specialists responsible for the proper LINK 16 terminals maintenance. GSS AGILE as a part of the whole ROSICZKA system enables to initiate platform terminals into LINK 16 network, solve problems that occur while logging into a network, evaluate correctness of network operation, analyze MIDS LVT terminal correct configuration, monitor and diagnose terminal operation. It also provides pilots with numerous possibilities of creating probable, virtual tactical situations and confronts them with particular tasks during air operations. The system provides a perfect tool capable of checking, verifying and evaluating actions taken by the scenario participants in response to various circumstances which can also be analyzed during debriefings after combat/ training missions are completed.

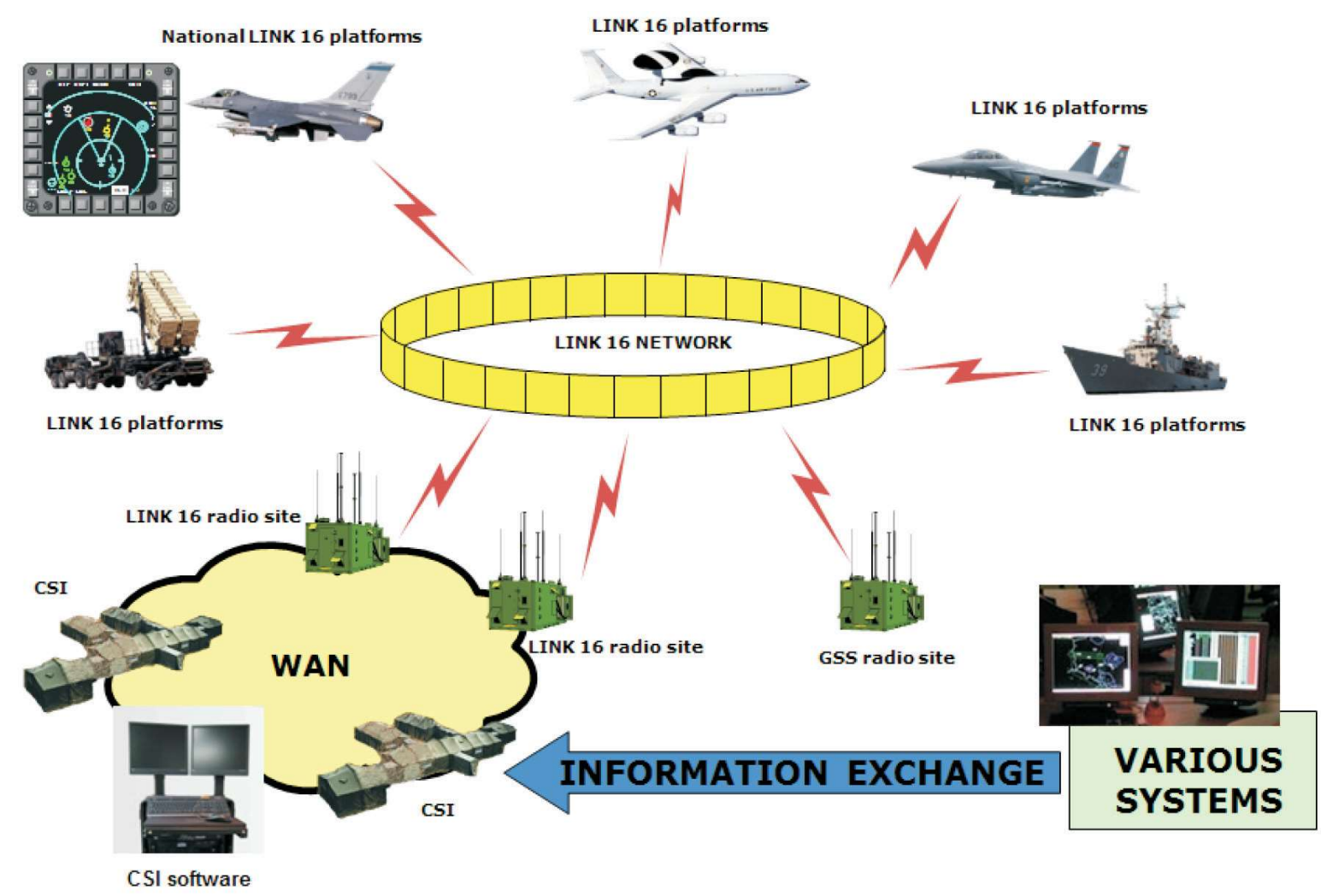

Fig. 1. Typical LINK 16 network architecture - vivid example of interoperability LINK 16 introduction to the Polish Armed Forces

The planning and implementation of LINK 16 tactical data system processes in Poland have started at the very beginning of this century. A special body - organizational unit has been established within the structure of General Staff of the Polish Armed Forces, tasked with completely new issues then, such as tactical data systems and global positioning systems called Tactical Data Systems and Navstar GPS Group. It was created in order to take care of all the aspects related to LINK 
16 implementation to the Polish Armed Forces. The Group was a precursor of a completely unknown issue then, uncharted territory and played a crucial role in the above mentioned process. After a Road Map to implement LINK 16 in the Polish Armed Forces had been proposed by the Group, it was given a seal of approval by the Chief of the Polish General Staff. A profusion of units and institutions such as the Armament Inspectorate, the Inspectorate for the Polish Armed Forces Support and the Polish Air Force Communications and Information Systems Center were tasked with particular activities in this respect thus starting to implement the planned objectives. The very first branch capable of using LINK 16 standard was the Polish Air Force simply due to the fact that Poland had already bought multirole F-16 jet fighters equipped with MIDS LVT terminals utilized in two Air Force Bases. Along with the aircraft, GSS AGILE (Ground Support System Aerosystems Generic Integrated Link Environment) site in Poznań-Krzesiny Base was set up. Its main purpose is to facilitate training of both platform/terminal operators (pilots) as well as ground crews, particularly avionics specialists responsible for the proper LINK 16 terminals maintenance. GSS AGILE as a part of the whole ROSICZKA system enables to initiate platform terminals into LINK 16 network, solve problems that occur while logging into a network, evaluate correctness of network operation, analyze MIDS LVT terminal correct configuration, monitor and diagnose terminal operation. It also provides pilots with numerous possibilities of creating probable, virtual tactical situations and confronts them with particular tasks during air operations. The system provides a perfect tool capable of checking, verifying and evaluating actions taken by the scenario participants in response to various circumstances which can also be analyzed during debriefings after combat/ training missions are completed.

Next elements of the system infrastructure implemented were terminal radio sites located throughout the country in such a way that the range in relation to aircraft at 5000 feet and above could be ensured. The radio sites' main purpose is to provide radio communications between air platforms equipped with terminals and:

- Air Operations Center - Air Component Command (AOC-ACC);

- $22^{\text {nd }}$ Control and Reporting Center (22 ${ }^{\text {nd }}$ CRC);

- $1^{\text {st }}$ Regional Control and Reporting Center ( $\left.1^{\text {st }} \mathrm{RCRC}\right)$;

- Deployable Control and Reporting Center (DCRC).

The above mentioned communications is a mean to command and control the air force assets. 


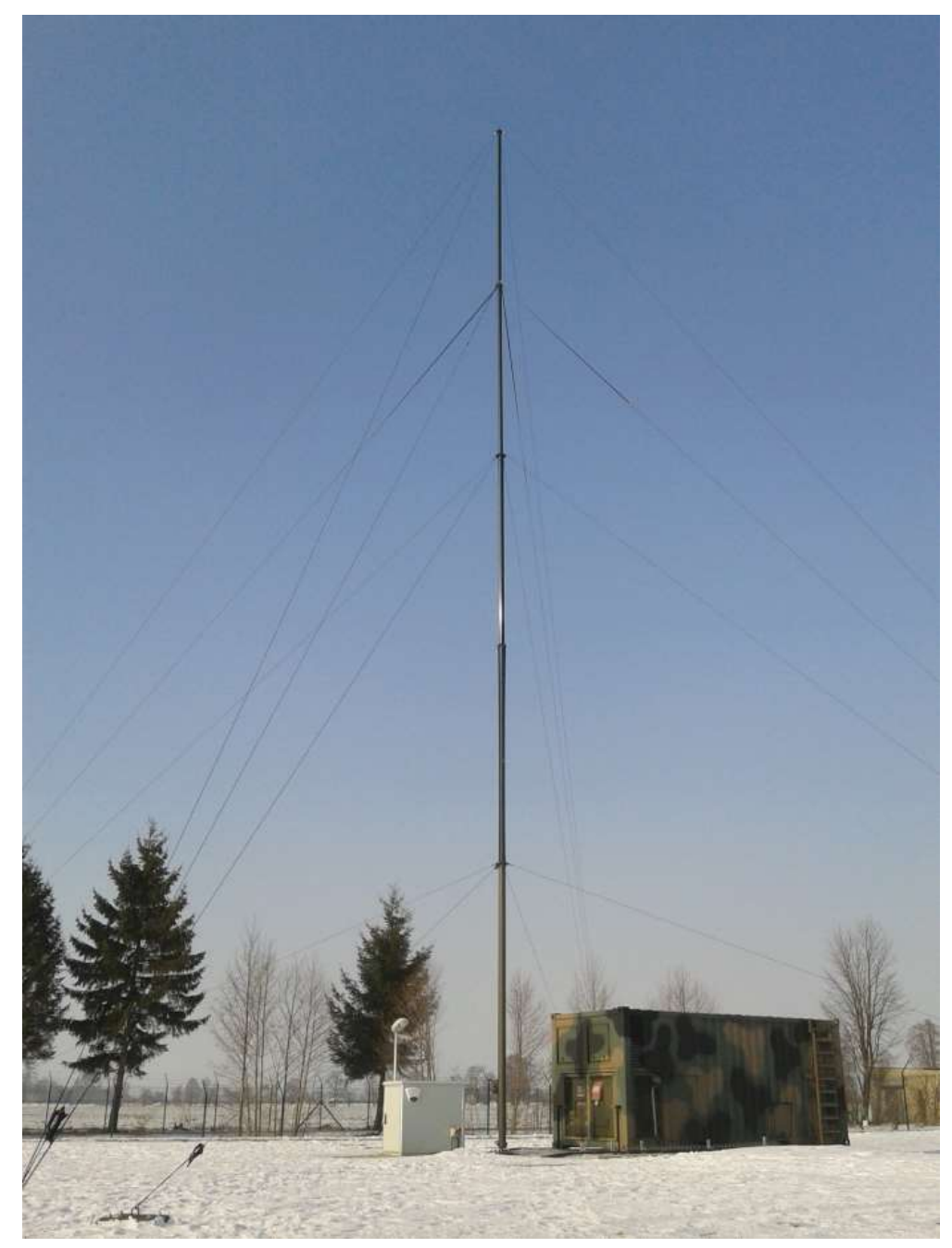

Fig. 2. Typical Polish LINK 16 radio site ${ }^{6}$

Further implementation steps within Polish Air Force meant setting up CSI's (Control and Reporting Center System Interface) located in AOC-ACC, $22^{\text {nd }}$ CRC, $1^{\text {st }}$ RCRC and DCRC each of which is an interface - gate between command system and platforms/systems based on tactical data links.

The Polish Tactical Data System based on LINK 16 standard came into operation in 2010 when one CSI and one radio site (based on building infrastructure, not shelters) were prepared and set in motion. Till the end of 2014 all the rest CSI's and terminal radio sites were put into operation. Most radio sites are based on shelters produced by the Military Communications Works No 1 S.A. - shelters called Mobile Modules of Command Post ${ }^{7}$ version 6 designed particularly for the Air Force branch.

It should be emphasized that the LINK 16 radio site based on the above mentioned shelter is an in - house project of the Tactical Data Systems Department of the

6 http://cwt.wp.mil.pl/pl/15_74.html

7 http://www.wzl1.com.pl/en/products 
PLAF CIS Center (currently the Department of Tactical Data and Radio Systems). They are unique when it comes to such assets all over the world. What is more, both System Security Officer and System Global Administrator come from PLAF CIS Center as well. The security documentation for the system designed to process data classified NATO SECRET, as one of the first such regulations in the Polish Armed Forces was also prepared by the above mentioned institution. The security documentation comprised of "System Security Specification", "Security Procedures", "Risk Analysis", and "Security Tests" was produced in accordance with both NATO and Polish regulations concerning classified information protection. Despite the fact that many consecutive versions have been generated along with the regulations and structural changes occurring in the system, the security documentation still makes up a perfect reference for other systems designed to process classified information.

The current state of affairs in terms of the system development is that new locations such as GSS AGILE in 32 $2^{\text {nd }}$ Air Force Base and platforms in other branches are being introduced and CSI in Navy Operations Center - Naval Component Command has just been implemented. The new, updated Road Map to implement LINK 16 in the Polish Armed Forces approved by the Chief of General Staff states that consecutive locations and platforms will be introduced in the Navy, Army and Special Force. What is more, NCIA (NATO Communications and Information Agency) has launched a project L16@29kft aimed at building terminal radio sites that will cover the radio range in Poland for aircraft at the ceiling of 29000 feet. Further plans are to integrate Rosiczka system with Air Command and Control System (ACCS) via special interfaces for CSI and LINK 16 radio sites at 5000 and 29000 feet.

Speaking about the LINK 16 implementation process it must be emphasized that a plethora of undertakings by the previously mentioned institutions have been carried out such as: purchasing equipment under national and international contracts, construction projects commissioned to Polish companies such as Hertz Systems Ltd Sp. z o.o., TTComm S.A. or TELBUD Sp. z o.o, IT infrastructure planning and building, security tests, accreditations that are inseparable with National Security Agency audits, technical and operational activation processes and personnel trainings both in Poland and abroad. Most technical and operational trainings related to tactical data links are performed by English speaking instructors but fortunately LINK 16 personnel is obliged to have certain language skills in accordance with STANAG 6001 - people who do not hold STANAG 6001 certificates are regularly enrolled on language trainings.

\section{LINK 16 implementation influence on the Polish Armed Forces}

The simple fact that Poland has been qualified to attend NATO tactical data link programs thus giving Poland an opportunity to access new LINK 16 standard 
related technologies proves that Poland is not just a nominal member of the North Atlantic Treaty Organization. Speaking of state security area it is a symptom of a good, strategic partnership with NATO and especially with the United States of America. Partnership, that means much more than just deep political dialogue, military and economic cooperation. "The Americans are aware of Poland as being a credible ally and partner, which has been proved not only once so far. They do realize that the Poles can see US readiness to take risks and make sacrifices when freedom and democracy are endangered. This mutual respect and good relations lead to concrete actions that will be more than just repaid when in need". That is why positively interpreting American arguments about missile defense system, quoting president George Bush after the meeting with Prime Minister Donald Tusk: The United States should play more active role in the process of the Polish Armed Forces modernization process, the example of which is LINK 16 implementation.

Efficiency, effectiveness and speed of tactical data links implementation in Poland as well as rich and productive participation of the Polish military representatives in international meetings, exercises and conferences in the area of tactical data links definitely make sizeable contribution to enhance good image of the Polish Armed Forces in the international arena. It is important to stress out that one of the periodical MIDS International Review Boards that is attended by all LINK 16 capable countries has been organized by Poland in Cracow, especially thanks to great efforts of the Tactical Data Systems and Navstar GPS Group from General Staff. The event received a very good feedback from all the participants. Polish military personnel thanks to their knowledge and broad experience often take part in many international meetings and conferences in order to help other countries with their processes of LINK 16 introduction at the very beginning stages of implementation and utilization. An example of this could be Polish-Romanian Cooperation. It is also worth mentioning that in April 2005 in Brussels an agreement between the Government of the Republic of Poland and Headquarters, Supreme Allied Commander Transformation (HQ SACT) was signed regarding the establishment and support of the NATO Joint Force Training Centre (JFTC) on the territory of the Republic of Poland, in Bydgoszcz. The Center was created with a view to supporting trainings of NATO forces and other countries under Partnership for Peace. One of the aims is also to improve interoperability issues of joint multinational military components (consisting of all the branches) and support SACT - Supreme Allied Commander Transformation in his/her tasks in his/her capacity as a NATO leading body when it comes to NATO transformation ${ }^{8}$. Apart from its important role in the NATO transformation process JFTC is directly involved in providing so called

8 Memorandum of agreement (MOA) between the Government of the Republic of Poland and Headquarters, Supreme Allied Commander Transformation (HQ SACT) regarding the establishment and support of the NATO Joint Force Training Centre (JFTC) on the territory of the Republic of Poland, Brussels, 2005. 
transformation products and services. Every year the Center with its Commandant (currently Polish brigadier general Wojciech Grabowski) organizes international interoperability exercise entitled CWIX (Coalition Warrior Interoperability Exploration, Experimentation, Examination, Exercise), that is attended by military and civilian LINK 16 technical and operational personnel. The exercise is a splendid opportunity for communications and information specialists to cooperate, solve interoperability problems with the use of various information technology environments based on tactical data links and share experience in this respect. During CWIX 2014 Poland was additionally to play an important part to help Ukrainian participants in terms of NATO regulations and exercise itself but due to the dangerous geopolitical situation Ukraine did not take part in the exercise.

The difficult situation in the East was also a factor that contributed to accelerate the implementation process of the Rosiczka system crucial elements based on LINK 16 standard. Since NATO decided to intensify efforts in order to evaluate the results of the Ukrainian crisis and its influence on NATO security, on $4^{\text {th }}$ March 2014 the North Atlantic Council (NAC) made a unanimous decision to use the early warning aircraft that is AWACS (Airborne Warning and Control System) in Polish and Romanian airspace with the aim of monitoring and controlling the situation. Such reconnaissance missions that are carried out only in the airspace of NATO members, with the use of aircraft stationed in Geilenkirchen in Germany and Waddington in Great Britain gave NATO a great advantage when it comes to information. Data received in such a way had to somehow be transferred to Combined Air Operations Center in Uedem in Germany. This was performed via newly implemented LINK 16 radio site and CSI through which Recognized Air Picture was transferred. The General Command of the Polish Armed Forces received a very good feedback from CAOC commander for great efforts to emergency implement the terminal radio site which had a significant positive impact on capabilities of SACEUR - Supreme Allied Commander Europe when responding to Ukrainian crisis.

The interoperability exercise in Bydgoszcz is not the only one that Poland takes part in actively. There are also many more national and international ones such as ANAKONDA, COBRA, NOBLE SWORD, STEADFAST JAZZ and many others by which combat capabilities can be demonstrated and evaluated. Some of these exercises could not be held without systems, based on LINK 16 standards, processing NATO SECRET data, that are often utilized in cooperation with other national and allied command and control systems. The exercises held periodically in Poland are strictly connected with the presence of NATO forces in Poland, perfect opportunities to share experience and utilize the most modern armament and equipment of our allies. It is often the case, that the equipment is left in Poland for a longer period of time on purpose, which is aimed at better familiarizing with it and later use of the knowledge acquired in such a way to plan modernization processes and purchasing equipment. 
Such trainings and increased presence of NATO forces in Poland (American or Belgian F-16's in Łask, French Dassault Rafale and Mirages in Malbork, and others) especially up against the difficult situation related to Ukrainian crisis are of great military and political importance. They indicate that NATO is not passive and take actions when its members are faced with crisis situations.

LINK 16 capability in the Polish Armed Forces enables Poland to fully participate in multilateral NATO trainings held abroad. Currently, it is possible thanks to our flagship MIDS LVT platforms, that is multirole F-16 jet fighters but with the consecutive points of the previously mentioned "Road Map" fulfilled, other branches of the Polish Armed Forces will also be capable of participating to the full in this respect. Poland's introduction to NATO political and military structures means not only rights and national security under the $5^{\text {th }}$ article of the Treaty but also certain responsibilities in capacity as an ally. That means that apart from trainings and peaceful operations we have already taken part in, we will also participate in solving various crisis situations or military conflicts all over the world. Allied military operations inseparably entail very high level of cooperation and interoperability which is ensured by, among others, secure information exchange via tactical data links.

LINK 16 implementation in Poland is one of the elements contributing positively to the process of structural, functional and technical rebuilding, redevelopment and improvements of the Polish Armed Forces aimed at adjusting them in terms of standards and equipment to NATO requirements in accordance with The Program of Integration with North Atlantic Treaty Organization and modernization of the Polish Armed Forces 1998-2012.

\section{Tactical data links in practice}

Let us suppose that in a certain area in the world, after all diplomatic, peaceful efforts ended with no success, United Nations Security Council decides that military operation is the only way to force the aggressor to leave the illegally occupied territory, to restore peace and stabilize geopolitical situation. In such circumstances allied countries start to deploy their forces with a view to achieving the planned goals of the international military operation. Success of such an enormous endeavour depends mainly on ability to exchange tactical information quickly and efficiently. The speed of data transmission is crucial especially because of large amounts of data being collected, processed and distributed which is quite typical of the warfare in the contemporary world. In order to rise to such a challenge all the Air, Naval, Army and Special forces with their assets must have immediate access to information. Let us presume that allied forces are comprised of allied forces command protected against air strikes with the batteries of PATRIOT guided missiles, operation control and coordination center separated from the command, special forces whose aim 
is to precisely determine enemy's locations, aircraft carriers, vessels equipped with maneuvering tactical missiles such as Tomahawk, fighters, bombers, electronic warfare, reconnaissance and multirole aircraft, AWACS at 29000 feet whose radars cover the area of more than $300000 \mathrm{~km}^{2}$, unmanned aerial vehicles who are continuously performing their mission of reconnaissance and fighter squadrons whose aim is to protect the command, aircraft carriers and other vessels. Before any action could be taken all the above mentioned participants should know precise positions of enemy's assets, detailed mission plan, as well as updated status and locations of the allied forces, which is necessary to efficiently coordinate the operation and use means and forces, that is to use minimal but adequate and sufficient assets to accomplish the planned goals and tasks, act and use the elements that are most adequate to certain set of circumstances (distance, armament, fuel left, etc.).

Taking all these into consideration, the commanders need to know what units, equipment and armament they have at their disposal, where their locations are, what they were tasked with recently and what their losses are. Speaking of Air Force the most crucial information is related to armament, fuel and health of all the sensors responsible for data collection. When such information is not available allied forces are more likely to be attacked by enemy's forces or even experience blue-on-blue incidents. Taking the above scenario into consideration it is easy to imagine how much information needs to be transferred between allied forces' elements and how often the data needs to be updated. Such requirements can be met with the use of tactical data system characterized by high throughput, reliability and security. MIDS LVT terminals are the very essential elements of such a system since they provide data distribution based on LINK 16 standard, thanks to which message service is standardized which in turn improves interoperability issues of the allied forces, especially that they do not use the same native languages. The standard allows the data to cover call signs, platform types, operation modes, units locations, parameters such as velocity, height, combat capabilities, armament at disposal, reconnaissance and command information.

Data received from reconnaissance centers and special forces (usually via satellites) is then transferred in LINK 16 "language" to command center at tactical level from where it is sent to all the participants in a form of orders or information. For instance the commander issues an order to AWACS about eliminating certain enemy's aircraft. Depending on a current tactical situation AWACS distributes tasks to destroy the targets to particular allied jet fighters. The fighters accept (or not) the tasks, carry out their missions and report about the results. This information is then sent from AWACS to commanders at tactical level.

LINK 16 based operations are very convenient since allied forces' locations are known all the time and commanders have a very clear picture of the situation and can make proper, best informed decisions. Moreover, information on actions taken 
by enemy's and allied forces and their results can also be securely transmitted directly or indirectly to commanders via reconnaissance measures and special forces.

What is interesting about the standard, is the fact that the process of data update does not take place at the same pace for every single LINK 16 network participant. The fastest update is offered to objects characterized by high speed such as fighter jets since situation, location, velocity and other factors and parameters change the most quickly. If the update frequency pace was identical for all the participants it might cause unwanted network overload. In order to avoid this negative feature there is also a technique allowing several users to share the same frequency channel by dividing the signal into different time slots called TDMA - Time Division Multiple Access 9 . This is another advantage of LINK 16 standard.

Taking everything into account, LINK 16 is a network system in which many of its participants share data through a special and very flexible network. Data can be transmitted via various means such as terrestrial radio waves, satellites, military IT networks and others. What is important, there is no center point of the network (so called nodeless feature) thanks to which it will work properly even in case some of its elements are destroyed. System based on LINK 16 standard is secure, resistant to jamming and it provides clear tactical situation picture which in turn ensures combat theatre management to be efficient and comprehensive and the losses are reduced to absolute minimum.

\section{Conclusion}

The Polish Armed Forces has gone through the implementation process of LINK 16 under the program Integrated systems supporting commanding and combat battle imaging - C4ISR that is one of many elements of a long-standing government program entitled Technical modernization priorities of the Polish Armed Forces as a part of operational programs. The introduction of such state-of-the art systems that enable fast and secure communications among assets, units and command centers will undeniably benefit the interoperability of the Polish Armed Forces and efficient cooperation with NATO members and Partnership for Peace program participants, which means Poland will be capable of fully participating in international exercises and operations. Therefore, it significantly contributed to the increase of Polish combat capabilities and consequently defense capabilities.

Polish participation in the LINK 16 program, the very fast pace and efficiency of implementation of the tactical data links in our country undoubtedly indicate that Poland is not a second-class but indeed a first-rate, fully-fledged NATO member. All of the above, in conjunction with our active role in both NATO and European

9 NATO Standardization Office NATO STANAG 5516 Tactical Data Exchange - Link 16, Brussels. 
Union structures contribute significantly to the increase of Poland's influence on the most important decisions made by international treaties and has its positive impact on stabilization of our region, especially Middle and East Europe. It is not surprising that the next NATO summit in 2016 will be held in Poland.

Conclusions and proposals that can be made in relation to the title of this article are that LINK 16 implementation should be continued and Rosiczka system based on the standard should be continuously developed and modernized. There is an urgent need to actively participate in NATO's efforts to ensure international security especially in the face of frequent threats related to global economics, economy, defense and terrorism. National security is one of the most essential values and priorities in the process of running a country. It is necessary then to aim at increasing national military potential, but taking into consideration financial and geopolitical reasons it should be emphasized that Poland needs to participate in programs organized by international treaties, not to rely only on its own capabilities.

\section{BIBLIOGRAPHY:}

1. ADatP-33 Multi-Link Standard Operating Procedures for Tactical Data Systems employing Link 16, Link 11, Link 11B, IJMS, Link 1 Link 4, and ATDL-1, Brussels.

2. Exposé 2008 - The Foreign Minister Mr. Radoslaw Sikorski’s brief on the Polish Foreign Policy in 2008, Warsaw, 2008.

3. Memorandum of agreement (MOA) between the Government of the Republic of Poland and Headquarters, Supreme Allied Commander Transformation (HQ SACT) regarding the establishment and support of the NATO Joint Force Training Centre (JFTC) on the territory of the Republic of Poland, Brussels, 2005.

4. NATO Standardization Office NATO STANAG 4175 Technical Characteristics of the Multi-functional Information Distribution System (MIDS), Volume 1, Brussels.

5. NATO Standardization Office NATO STANAG 5501 Tactical Data Exchange - Link 1, Brussels.

6. NATO Standardization Office NATO STANAG 5511 Tactical Data Exchange - Link 11, Brussels.

7. NATO Standardization Office NATO STANAG 5516 Tactical Data Exchange - Link 16, Brussels.

8. NATO Standardization Office STANAG 5522 Tactical Data Exchange - Link 22, Brussels.

9. NATO Standardization Office NATO STANAG 5616 Standards for Data Forwarding between Tactical Data Systems employing Link 11/11B and Link 16, Brussels.

10. www.datalinksolutions.net/dls.

11. www.euromids.com.

12. www.viasat.com.

13. www.rockwellcollins.com. 


\section{WDROŻENIE STANDARDU „LINK 16” PRZEZ POLSKIE SIŁY ZBROJNE A WPŁYW NA MOŻLIWOŚCI OBRONNE, BEZPIECZEŃSTWO NARODOWE ORAZ POSTRZEGANIE POLSKI JAKO CZŁONKA NATO}

Streszczenie. W artykule ukazano historię powstawania TSTD (Taktycznych Systemów Transmisji Danych) na świecie, ich ogólną budowę i przeznaczenie w państwach będących członkami Paktu Północnoatlantyckiego, ze szczególnym uwzględnieniem standardu LINK 16. Scharakteryzowano wpływ wdrożenia systemu LINK 16 w Siłach Zbrojnych RP na wzrost interoperacyjności Polski jako pełnoprawnego członka NATO, a tym samym zwiększenie zdolności obronnych, bezpieczeństwa państwa i umocnienie dobrego wizerunku Polskich Sił Zbrojnych na arenie międzynarodowej. Ponadto przedstawiono przykłady zastosowania TSTD w czasie ćwiczeń, w warunkach pokojowych oraz podczas rozwiązywania konfliktów na świecie.

Słowa kluczowe: Link 16, systemy zbierania danych taktycznych, bezpieczeństwo danych, Siły Zbrojne RP, NATO. 